\title{
A Comparative Analysis of Economic Farming Activity of Farmers Rice-Livestock Integrated Farming System (RLIFS) and Non RLIFS
}

\author{
L Lindawati ${ }^{1}$, Mhd. Buhari Sibuea ${ }^{2}$, Desi Novita ${ }^{1}$ Muhammad Ilham Riyadh $^{1}$, Abdurrozzaq Hasibuan ${ }^{3}$ \\ ${ }^{I}$ Department of Agribusiness, Faculty of Agriculture, Universitas Islam Sumatera Utara, Medan, Indonesia \\ ${ }^{2}$ Department of Agribusiness, Faculty of Agriculture, Universitas Muhammadiyah Sumatera Utara, Medan, Indonesia \\ ${ }^{3}$ Department of Industrial Engineering, Faculty of Engineering, Universitas Islam Sumatera Utara, Medan, Indonesia \\ *Corresponding author E-mail: lindatan84@fp.uisu.ac.id
}

\begin{abstract}
Integrated farming system is a system that emphasized linkages and synergism of farming units waste utilization. The objective of this study was to analyze the economic farming activity of Rice Livestock Integrated Farming System (RLIFS) and non RLIFS farmers. The results showed the usage allocation of family and external labor to RLIFS farmers was relatively greater than non RLIFS farmers. The RLIFS farmers' income of rice farming, other crops and non-agricultural was relatively larger than non RLIFS farmers, while non RLIFS farmers had greater income from livestock (cow and non cow) business and farm labor. The production costs of rice farming and livestock business were still greater in RLIFS farmers although they used manure produced by their own and also provide straw of rice production as animal feed. This was due to several factors (1) The proportion of the cost of using manure was very small in the cost of rice farming if the use of manure only a supporting fertilizer and not the main fertilizer for plant. (2) Some farmers were still buying and using anorganic or chemical fertilizers because of their mindset who wanted fast and instantaneous ones. Some farmers also felt that manure contained less nutrients so they used it in small quantities. The household income total of RLIFS farmers was higher than non RLIFS farmers.
\end{abstract}

\section{Introduction}

The contraction of the rice field area requires an agricultural technology that is able to encourage the production increasing without having to increase land area. Intensification of agricultural systems is appropriate to resolve the issue. The problems arise when the use of chemical inputs is disproportionate that causes degradation of soil fertility and declined the income of farmers[1]. Soil fertility improvement requires a systematic and gradual effort in reducing the use of high external input with low external input. One of the efforts in addressing these problems was the implementation of an integrated farming system. Integrated farming system is a system that emphasized the existence of linkages and synergism several units of farming (crops, livestock, fisheries and plantations) through the utilization of farming waste from each unit of farming that aims to increase production[2]. Integrated farming system is capable of restoring the fertility of the soil and stabilize the incomes of farming [3]. Rice-livestock integrated farming system (RLIFS) is an environmentally friendly technology and appropriately done for several reasons; (1) support a nature conservation which the integration used the concept of zero waste that minimize waste by recycling process, (2) minimize the use of chemical inputs.

\section{Literature Review}

The implementation of an integrated farming system generally has a positive and negative impact. Integrated farming system gave positive impact and was able to increase production and income significantly[4], [5], [6]. Integrated farming system gave negative impact which the efficiency of labor and capital usage on the Minapadi farming system was lower than the farming of rice monoculture[7]. The study [8] showed that the integrated farming system positively impact like rice-cocoa-livestock program at Donggala, Indonesia. This is due to the availability of cocoa rind as the raw material was very low caused by the pests stricken and the difficulty of obtaining probiotics for the making of animal feed [8]. The study at Zhujian River delta, China suggested that the integrated farming system of sugar cane farming, fisheries, mulberry leaves and silkworm gave negative impact on farmers' profit. The low availability of input was low, causing high production costs so the profit became smaller [9].

\section{Research Method}

The study was conducted at West Java province as one of the provinces that ever implemented the program of Rice-livestock 
integrated farming system (RLIFS). Furthermore purposively selected Subang, Sumedang and Tasikmalaya as research location The sample of the study were farmers of Rice-livestock integrated farming system (RLIFS) and non RLIFS. Determination of samples was done by the method of purposive sampling. The number of samples as many as 199 farmers consists of 134 RLIFS farmers and farmer 65 non RLIFS farmers.

The analysis method used economic analysis of farming which calculated labor allocation, the agricultural production, the structure of production cost and income of farming by using economic principles of farming production.

\section{Results and Discussion}

\section{Characteristics of The Farmer Respondents}

The characteristics of farmers and household members included the average age, level of formal education, the number of the household members and the age of the work force in a household to describe the performance of or the potential of such activities in a household work or other activities. The characteristics indicator used generally give you an idea of the existence of a positive relationship between the indicators of economic activity and other activities in the household. This study approved a study of [10] Omonona et al. (2010) that mentioned the characteristics of farm households was important. Heads of households who were at productive age would have a positive impact on household performance compared to unproductive . Likewise the level of education and the number of household members of the working age (labor force) would have a positive impact on economic performance and other household activities.

Table 1. Characteristics of the Farmer Respondents

\begin{tabular}{|l|c|c|}
\hline \multicolumn{1}{|c|}{ Description } & RLIFS Farmer & $\begin{array}{c}\text { Non } \\
\text { RLIFS } \\
\text { Farmer }\end{array}$ \\
\hline Number of respondents (people) & 134 & 65 \\
\hline Age of husband (year) & 48.142 & 49.385 \\
\hline Age wife (year) & 42.052 & 43.185 \\
\hline Husband's education (year) & 6.799 & 6.477 \\
\hline Wife' education (year) & 6.411 & 6.385 \\
\hline Number of family members (people) & 3.612 & 3.569 \\
\hline Number of schoolchildren (people) & 0.731 & 0.892 \\
\hline Family workforce (people) & 2.664 & 2.615 \\
\hline
\end{tabular}

It was generally stated that the average age of wives and husbands of RLIFS and non RLIFS farmers were in productive age ranging from 20 to 73 years and 26 to 75 years (Table 1). The considerable age span indicated that most farmers considered the farming activities of RLIFS to be an activity that could provide additional income opportunities and consider livestock business as a savings that can be sold when needed.

The average number of family members for RLIFS farmers was 3.61 people and 3.57 for non RLIFS farmers. While for the average labor force of each was 2.67 people and 2.62 people per farm household. The family workforce was measured by the number of family members of the same age or over 15 years. This showed that there was a tendency of higher number of family members, the greater the number of family workforce available. Family size could be seen from two sides, namely as the potential availability of labor owned by the farmer's household and on the other hand was the burden of family dependents.

\section{Mastery of Agricultural Resources}

Rice-livestock integrated farming system (RLIFS) as been a culture that was carried out for generations in West Java. Alignment or integration of rice-livestock was generally carried out either collectively or individually. Collectively, if there was government assistance received by farmer groups in the area, however there were farmers who implemented independently either because of the awareness of the need for chemical fertilizer reduction for rice crops.
Table 2. Mastery of Agricultural Resources

\begin{tabular}{|l|c|c|}
\hline \multicolumn{1}{|c|}{ Description } & $\begin{array}{c}\text { RLIFS } \\
\text { Farmer }\end{array}$ & $\begin{array}{c}\text { Non RLIFS } \\
\text { Farmer }\end{array}$ \\
\hline Area of rice field (Ha) & 0.190 & 0.165 \\
\hline Area of the field (Ha) & 0.160 & 0.123 \\
\hline Rice production (kg / year) & 9.475 & 8.694 \\
\hline Manure production (ton/year) & 3.183 & 0.000 \\
\hline Production of cow cattle (livestock units) & 1.058 & 1.057 \\
\hline Number of non cows (livestock units) & 0.378 & 0.716 \\
\hline
\end{tabular}

On mastery of agricultural resources, rice field area, rice production, manure production and the number of cow of RLIFS farmers was relatively higher than non RLIFS farmers (Table 2). This indicated that farmers felt greater benefits and advantages by implementing integrated farming system of rice-livestock. The more extensive rice field area, so the more straw and rice production. Rice production from RLIFS farmers was relatively higher $(9.48$ tons/Ha) while non RLIFS reached about 8.69 tons/Ha. Increasing production of rice could provide the availability of animal feed throughout the year. The waste from livestock like crap of livestock could be utilized as manure so that RLIFS farmers were able to produce manure about 3,183 tons/Ha per year. The use of manure as a one of fertilizer source could also increase rice production of RLIFS farmers until about 0.78 tons/Ha.

\section{Production}

The average production of rice for farmers in research location was $9.22 \mathrm{ton} / \mathrm{Ha}$ in a year. This showed that the productivity of farmers who conducting activities of rice-livestock integrated farming system was quite high even exceeding the average productivity in 6 subdistrict (Table 2).

During the dry season, some farmers did not grow rice due to lack of water supply but planted crops and horticulture such as cassava, corn, peanuts and cucumbers. Plants such as maize, peanuts and cucumbers were planted in rice fields during the dry season, but cassava was grown in the field because the sweet potato plant has a long growing period and disturbs the rice cropping pattern that were the main commodity. Some other commodities grown in the field include sweet potatoes, pepper, cucumber and also wood. Average productivity of maize was 4,278 tons/Ha, peanuts and cassava respectively 1,124 and 5.79 tons/ha. Farmers who had fields also earn extra income from harvesting timber every 5 - 7 years. Some types of wood grown include abazia, sobsi, sengon, mahogany, teak and another. Generally farmers planted timber species that can be harvested 5 - 7 years such as abazia, sobsi and sengon. Wood production was partly sold but there were also used for their own needs that was when making a house building for family members of farmers.

Table 3. The average agricultural production per year

\begin{tabular}{|c|c|}
\hline Description & Production \\
\hline Corn production (ton/Ha) & 4.278 \\
\hline Peanut production (ton/Ha) & 1.124 \\
\hline Cassava production (ton/Ha) & 5.790 \\
\hline Cucumber production (ton/Ha) & 0.714 \\
\hline Sweet potato production (ton/Ha) & 1.429 \\
\hline Banana Production (ton/Ha) & 1.506 \\
\hline Wood production (ton/Ha) & 4.345 \\
\hline
\end{tabular}

The average of livestock crap per farmer in one day was $36.5 \mathrm{~kg}$. According to Blakely and Bade (1995), feces of dairy cow and bull about $8-14 \mathrm{~kg}$ per day while the calf about $4 \mathrm{~kg} / \mathrm{day}$. The potential of this crap if utilized entirely will produce manure 14.6 $18.25 \mathrm{~kg}$ per day or $3.65-4,563$ tonnes/farmer household per year. However, in the current research, the crap was not entirely used to be manure. Most farmers used only about $40-50 \%$ and some even didn't use the crap as fertilizer in rice farming. The livestock crap that used to manure has shrunk to $50 \%$. Processing into manure actually was a simple process but requires a long time and a lot of work to be applied to the rice fields.

\section{The Use and Outpouring Labor}

The use of labor was allocated for rice farming, the cow cattle business, crops other than rice, and off-farm business. The use of 
labor was differentiated according to the labor of husband, wife and children with the calculation of Working Day (WD) in a year. Overall, the outpouring of both the family labor and external labor of RLIFS was greater than others (Table 4). This was allegedly related to the wider harvested rice area owned by their households in the region. The average use of family labor in a year on rice business for RLIFS farmers was 23.32 Working Day (husband) and 19.54 Working Day (wife).

Table 4. The number and the average of outpouring labor (Working Day)

\begin{tabular}{|l|c|c|}
\hline \multicolumn{1}{|c|}{ The use of Labor } & $\begin{array}{c}\text { RLIFS } \\
\text { Farmer }\end{array}$ & $\begin{array}{c}\text { Non } \\
\text { RLIFS } \\
\text { Farmer }\end{array}$ \\
\hline Family Labor of Rice Farming & & \\
\hline Husband & 23.324 & 22.413 \\
\hline Wife & 19.542 & 17.102 \\
\hline Child & 0.000 & 0.029 \\
\hline External Rice Farming Workforce & & \\
\hline Man & 6.473 & 4.593 \\
\hline Woman & 11.935 & 8.192 \\
\hline Livestock Business Workers & & \\
\hline Husband & 180.494 & 170.481 \\
\hline Wife & 24.612 & 13.308 \\
\hline Child & 0.68 & 2.808 \\
\hline On the
\end{tabular}

On the use of family labor for the cow cattle business, where RLIFS farmers used family labor which was relatively larger compared to others. The average use of family labor in a year in livestock business for them was 180.5 Working Day (husband) and 24.61 Working Day (wife). The use of family labor for livestock enterprises was dominated by husbands in activities to feed the animals by collecting straw and grass, sanitation and cage maintenance. The biggest employee outpouring was in the activity of gathering grass and straw while the labor outpouring on livestock grazing activities was very small. This was related to regional topography which was difficult to graze livestock so that the average of the cow cattle are stacked in the research location. Meanwhile, the largest labor outpouring wife in the cow cattle business was on the activity of collecting straw and grass. The out pooring of child labor on the cow cattle business was generally on sanitation and care of cages and herding cattle. The use of child labor was very little in rice farming because the general shortage of manpower in this region was solved by the use of external labor. The use of external labor for rice farming was generally dominated by women due to the relatively low female wage of Rp 15000 Rp 20000 per day, while the male workforce was Rp 30000 - Rp 35000 per day. Outpouring of external women labor was generally for harvesting, planting and weeding. Meanwhile, the use of external man labor for rice farming was the largest in the processing of land and harvest.

\section{Cost of Production Factor, Revenue and Income}

The largest contribution of household revenue to RLIFS and non RLIFS farmers was from the cow cattle business which was $47.20 \%$ and $50.50 \%$, then rice farming was $24.02 \%$, and $23.66 \%$ and non farm revenue $15 \%$ and $10.18 \%$. This percentage indicates that the cow cattle business opportunities were larger in the research area The small contribution from rice farming revenues was caused by several things, among others 1) the average land area of the farmers was relatively small enough that was smaller than $0.2 \mathrm{Ha}, 2$ ) the influence of the dry season so that farmers plant rice only 1 to 2 time a year.

The average rice production cost of RLIFS farmers was relatively higher compared to others. This was in line with the rice harvest owned by them which were relatively broader than non RLIFS farmers so they got more revenue from that farming.. The livestock production cost of RLIFS farmers larger than others because more usage of labor and animal feeds at that livestock business. However the livestock business income of RLIFS farmers lower than others which was Rp 4891976 and Rp 6049579 respectively. This was due to they had a lower number of non cow cattle like goats, sheeps, buffalo, pigs and chickens so they got more revenue from that business.
Table 5. The average of factor production cost, revenue and income

\begin{tabular}{|c|c|c|}
\hline \multirow{2}{*}{ Description } & RLIFS & Non RLIFS \\
\hline & Farmer & Farmer \\
\hline \multicolumn{3}{|l|}{ Production cost: } \\
\hline Rice & 795365 & 60645 \\
\hline Cow & 925725 & 84826 \\
\hline \multicolumn{3}{|l|}{ Labor costs: } \\
\hline Rice farming & 1397711 & 123741 \\
\hline Livestock business & 5912681 & 543575 \\
\hline Total Cost & 9031482 & 812789 \\
\hline \multicolumn{3}{|l|}{ Revenue: } \\
\hline Rice farming & $\begin{array}{r}5829173 \\
(24.02 \%) 5 \\
\end{array}$ & $5370051(23.66 \%$ \\
\hline Cow cattle business & $\begin{array}{r}11453218 \\
47.20 \%) \\
\end{array}$ & $\begin{array}{r}1146475 \\
(50.50 \% \\
\end{array}$ \\
\hline Other plant farming & $\begin{array}{c}2603694 \\
(10.73 \%) 2\end{array}$ & $2109231 \quad(9.29 \%$ \\
\hline Non cow cattle business & $277164(1.14 \%)$ & $868846 \quad(3.83 \%$ \\
\hline Farm labor & $464440 \quad(5.54 \%)$ & $576539 \quad(2.54 \%$ \\
\hline Non agriculture & $\begin{array}{l}3639739 \\
(15.00 \%)\end{array}$ & $2311231(10.18 \%$ \\
\hline Total revenue & $\begin{array}{r}24267428 \\
(100 \%) \\
\end{array}$ & $\begin{array}{r}22700648 \\
\quad(100 \% \\
\end{array}$ \\
\hline \multicolumn{3}{|l|}{ Income: } \\
\hline Rice & 3636097 & 3526178 \\
\hline $\begin{array}{l}\text { Plant (rice and other plant) farming } \\
\text { (1) }\end{array}$ & 6239791 & 5635409 \\
\hline Cow cattle business & 4614812 & 5180733 \\
\hline $\begin{array}{l}\text { Livestock (cow and non cow) busi- } \\
\text { ness (2) }\end{array}$ & 4891976 & 6049579 \\
\hline Other Income (3) & 4104179 & 2887770 \\
\hline Total Income $(1+2+3)$ & 15235946 & 14752758 \\
\hline
\end{tabular}

The use of manure to crops can increase production and income. This was indicated by the comparison of production and income of rice farming from farmers. The farmers of RLIFS had rice production and income from rice farming was greater than non RLIFS farmers. This study concured with the research done by some other researchers [4], [6], [11] that integrated agriculture is able to increase production and income.

The RILFS farmers' income contribution mainly came from rice farming, other crops and other non-agricultural income. The contribution of non RILFS farmers was mainly from cattle, non cattle and farm laborers. The total income difference between the two groups of farmers was not very large, namely Rp 15235946 and Rp 14752758 respectively for RLIFS and non RLIFS farmers. There was a considerable contribution to rice farming, other crops and other non agricultural income causing the total household income of RLIFS farmers was higher than others. The production costs of rice farming and livestock business were still greater in RLIFS farmers although they used manure produced by their own and also provide straw of rice production as animal feed. This is due to several factors (1) The proportion of the cost of using manure was very small in the cost of rice farming if the use of manure only a supporting fertilizer and not the main fertilizer for plant. (2) Some farmers were still buying and using anorganic or chemical fertilizers because of their mindset who wanted fast and instantaneous ones. Some farmers also felt that manure contained less nutrients so they used it in small quantities.

The average total income of RLIFS farmers in a month was Rp 1 269 662, relatively higher than non RLIFS farmers which amounted to Rp 1214 397. When compared tostandard based of poverty line on per capita income of Rp 312328 per month (BPS 2014), It can be stated that farmers in the research area were not included in the category of poor farmers because they are above the poverty line

\section{Conclusion}

a. The area of rice harvest, rice production, cow cattle production of RLIFS farmers' was relatively higher than non RLIFS farmers

b. The usage allocation of family and external labor to RLIFS farmers was relatively greater than non RLIFS farmers. 
c. The RLIFS farmers' income of rice farming, other crops and non-agricultural was relatively larger than non RLIFS farmers, while non RLIFS farmers had greater income from livestock (cow and non cow) business and farm labor.

d. The household income total of RLIFS farmers was higher than non RLIFS farmers

e. The production costs of rice farming and livestock business were still greater in RLIFS farmers although they used manure produced by their own and also provide straw of rice production as animal feed. This is due to several factors (1) The proportion of the cost of using manure was very small in the cost of rice farming if the use of manure only a supporting fertilizer and not the main fertilizer for plant. (2) Some farmers were still buying and using anorganic or chemical fertilizers because of their mindset who wanted fast and instantaneous ones. Some farmers also felt that manure contained less nutrients so they used it in small quantities.

\section{Limitation and Further Research}

a. The results showed that the production of manure was carried out independently and has not been managed properly and optimally. Production of manure was used to meet the needs of fertilizer itself or subsistence.

b. The limitations of this study calculated the weight of cow cattle in livestock units converted into kilograms. Another limitation is that the cost of producing non-cow cattle and nonrice was not calculated separately because it has been included in the main farm.

c. An integrated farming system of rice-livestock can be an alternative government policy to be developed in the countryside but a comprehensive concern is needed regarding the influence of external factors affecting the sustainability of the integrated farming system.

d. Need further research related to the utilization of other crop wastes other than rice and cow livestock waste are interrelated between each farming of other rice/crops and cattle and noncattle farming

e. Need further research on institutional integrated farming. Preliminary observations indicate that the production of manure was quite good and the number was quite large if managed in a farmer group.

\section{References}

[1] A. J. A., Integrating research on food and the environment: An exit strategy from the rational fool syndrome in agricultural science, 5th ed. Ecol. Soc., 2001.

[2] M. F and K. N., "Model Usahatani Terpadu Sayuran OrganikHewan Ternak (Studi Kasus:Gapoktan Pandan Wangi, Desa Karehkel, Kecamatan Leuwiliang, Kabupaten Bogor)," Forum Agribisnis, vol. 1, no. 1, pp. 76-94, 2011.

[3] L. C and M. D. R, "Farmer-first qualitative methods: Farmers diagrams for improving methods of experimental design in integrated farming systems," J. Farming Syst. Res. Ext., vol. 2, pp. 11-34, 1991

[4] C. A. S and B. D. P., "Relative Performance of Different Rice-FishPoultry Integrated Farming System Models with Respect to System Productivity and Economics," Karnataka J. Agric. Sci., vol. 20, no. 4, pp. 706-709, 2007.

[5] P. A., ampak Program Sistem Integrasi Tanaman-Ternak terhadap Alokasi Waktu Kerja, Pendapatan dan Pengeluaran Rumah Tangga (Published Doctor's Dissertation). Bogor: Institut Pertanian Bogor, 2007.

[6] N. M. S. E, V. R, and S. N, Demonstration and replication of integrated farming systems at Chidambaram M. S. Swaminathan Research Foundation. Chennai, 2009.

[7] D. E. M. T. C, "Comparative Productivity, Profitability, and Efficiency of Rice Monoculture,” J. Sustain. Agric., vol. 29, no. 1, pp. 145-160, 2006.

[8] H. S, Model Integrasi Tanaman-Ternak di Kabupaten Donggala Provinsi Sulawesi Tengah: pendekatan optimasi program linier (Unpublished Master's thesis). Bogor: Institut Pertanian Bogor, 2009.
[9] R. K. Z. G, Integrated Agriculture-Aquaculture in South China: The Dike-Pond System of The Zhujian Delta. Cambridge University Press.

[10] O. BT, L. JO, and O. AO, Determinants of credit constraint conditions and production efficiency among farming households in Southwestern Nigeria. Presented at the Joint 3rd African Association of Agricultural Economists (AAAE) and 48th Agricultural Economists Association of South. Cape Town, South Africa.

[11] J. C, V. C, N. K, and C. B, "Sustainable integrated management of crop with allied enterprises- Ensuring livelihood Security of Small and Marginal Farmers. Special Feature: Sustainable Agriculture.," 2009. 